\title{
Biliary Immunoglobulins in Protein-Energy Malnourished Rats
}

\author{
Fumio SHIMURA, Junko SHIMURA, and Norimasa HosoyA ${ }^{1}$ \\ Department of Nutrition, School of Health Sciences, \\ Faculty of Medicine, University of Tokyo, \\ Bunkyo-ku, Tokyo 113, Japan \\ (Received December 15, 1982)
}

\begin{abstract}
Summary The effect of protein-energy malnutrition on biliary immunoglobulins was investigated in rats fed isocaloric diets containing $0.5 \%$, $5 \%$, and $18 \%$ casein, respectively. Growth was severely retarded in rats fed $0.5 \%$ casein diet and moderately in rats fed 5\% casein diet, and these groups had decreases in serum albumin and total protein levels. Since the energy intake was low in rats fed protein-insufficient diets, the nutritional status was defined not as protein malnutrition but protein-energy malnutrition.

Depression of systemic immune functions in protein-energy malnourished rats were demonstrated by serum IgG and IgA levels, and antibody responses to dinitrophenylated bovine gamma globulin, a T-cell dependent antigen. The depressed systemic immune functions observed in those rats were suggested to be caused by thymic atrophy.

IgA levels in bile were much higher in all groups than IgG levels. IgG levels decreased in rats fed $0.5 \%$ casein diet but not in rats fed $5 \%$ casein diet, while IgA levels decreased in rats fed $5 \%$ and $0.5 \%$ casein diet relating to casein levels. The ratios of IgA to IgG in bile also decreased in rats fed protein-insufficient diets. By sucrose density gradient centrifugation secretory $\operatorname{IgA}$ levels in bile were shown to decrease in rats fed $0.5 \%$ casein diet, suggesting that the secretion of IgA by hepatic parenchymal cells is depressed in the protein-energy malnourished rats.

Key Words biliary $\operatorname{IgA}$, secretory $\operatorname{IgA}$, intestinal immunity, proteinenergy malnutrition
\end{abstract}

It is now recognized that nutritional deficiency affects several facets of host resistance (1-5). Children with protein-energy malnutrition (PEM), mainly kwashiorkor, have increased incidences of bacterial, fungal, and viral infections (1-5).

1 志村二三夫，志村純子，細谷憲政

Abbreviations: PEM, protein-energy malnutrition; IgG, immunoglobulin G; IgA, immunoglobulin A; sIgA, secretory IgA; SC, secretory component; DNP-BGG, dinitrophenylated bovine gamma globulin; DNP-lys, dinitrophenyl-lysine. 
Impaired immune functions in PEM seem to increase the susceptibility to infections $(1-5)$. Infectious diseases in the gastrointestinal tract cause malabsorption of nutrients, leading to further malnutrition.

Intestinal antibodies have been considered important in preventing the penetration into the gastrointestinal wall of some pathogenic microorganisms, toxic agents, and other substances which are recognized as nonself by the host immune system (6). The most predominant intestinal antibody is $\operatorname{IgA}(6-9)$. Intestinal $\operatorname{IgA}$ has a unique structure which consists of dimeric $\operatorname{IgA}$, J-chain, and secretory component, and is called secretory $\operatorname{IgA}(\mathrm{sIgA})$ to be distinguished from serum $\operatorname{IgA}(7,10)$. It has been thought that intestinal antibodies are supplied principally by IgA-producing plasma cells in the lamina propria and secreted through the intestinal epithelium (7). However, recent studies have shown that bile contains high concentrations of IgA (11-14), and the bile duct cannulation significantly decreases IgA levels in the intestinal lumen (14). These observations suggest that biliary IgA has an important role in the local defense mechanisms of the intestinal tract. Changes in biliary antibodies, especially in the IgA class, may account for the increased susceptibility to intestinal infectious diseases associated with PEM. The purpose of the present study is to investigate the effect of experimental PEM on biliary immunoglobulins, especially IgA.

\section{METHODS}

Animals. Male, Sprague-Dawley rats, body weight of $100 \mathrm{~g}$, were purchased from Charles River Breeding Company, Japan. Eighteen rats were divided into three different dietary groups. Throughout the experiment (40 days), the control group was fed $18 \%$ casein diet and the others were fed $5 \%$ and $0.5 \%$ casein diet, respectively. Diets and water were given ad libitum. The feed consumption was calculated by subtracting the weight of the droppings from that of the supplies. On the 26th day of the experiment, the rats were subcutaneously injected with $1 \mathrm{mg}$ of DNP-bovine $\gamma$-globulin (DNP-BGG) which was emulsified with Freund's complete adjuvant. One week after the primary injection, the rats were boosted intramuscularly with DNP-BGG solution $(0.5 \mathrm{mg} / \mathrm{rat})$. On the 40 th day bile was collected by bile duct cannulation(15) after anesthetizing the rats with sodium pentobarbital $(2.5 \mathrm{mg} / 100 \mathrm{~g}$ of body weight, intraperitoneally). After $c a .1 \mathrm{ml}$ of bile was collected, the rats were decapitated and blood was obtained. Serum was separated after blood clotted. Bile and serum were kept at $-20^{\circ} \mathrm{C}$ until used.

Determination of immunoglobulin levels. The concentration of $\operatorname{IgG}, \operatorname{IgA}$, or albumin was determined by radial immunodiffusion (16). Standard protein of IgG was isolated from rat serum (17). sIgA was purified by a modification of the method of Fisher et al.(18). Briefly, sIgA was precipitated from rat bile by ammonium sulfate and chromatographed on DEAE-Sephadex A-25. Further purification was performed by gel filtration on Sephadex G-200 and Sepharose 6B. Anti-rat IgG serum was raised in rabbits and absorbed on an immunoadsorbent column (light 
chain conjugated to Sepharose 4B). Goat anti-rat IgA antiserum ( $\alpha$-chain specific) was purchased from Miles Lab. Rabbit anti-rat albumin antiserum and rat serum containing known albumin concentration were generously provided by Dr. Y. Shidoji. $^{2}$

Determination of dinitrophenyl-lysine binding activities. Specific hapten (dinitrophenyl-lysine: DNP-lys) binding activities in serum and bile were determined by the method of Hanson et al.(19) with a little modification. Briefly, $100 \mu \mathrm{l}$ of serum (10-fold diluted) or bile was incubated with $30 \mathrm{pmol}$ of $\varepsilon$-[phenyl3,5- $\left.{ }^{3} \mathrm{H}(\mathrm{N})\right]$-dinitrophenyl-L-lysine $\left(\left[{ }^{3} \mathrm{H}\right]-\mathrm{DNP}-1 \mathrm{ys}: 5.04 \mathrm{Ci} / \mathrm{mmol}\right.$ (New England Nuclear)) at $4^{\circ} \mathrm{C}$ for $15 \mathrm{~h}$ in the absence or presence of $3 \mathrm{nmol}$ of unlabeled DNP-lys. To the mixture polyethylene glycol $(10 \%(\mathrm{w} / \mathrm{v})$ of final concentration) was added, stirred vigorously, and placed at $0^{\circ} \mathrm{C}$ for $1 \mathrm{~h}$. The precipitate was then separated by centrifugation at $2,000 \times g$ for $1 \mathrm{~h}$ at $4^{\circ} \mathrm{C}$, and the radioactivity in the precipitate was counted in a liquid scintillator (Omnifluor (New England Nuclear) : naphthalene : dioxane at $5 \mathrm{~g}: 100 \mathrm{~g}: 1$ liter). $\left[{ }^{3} \mathrm{H}\right]$-DNP-lys in the precipitate in the absence and the presence of unlabeled DNP-lys were expressed as total binding and nonspecific binding, respectively. Specific binding is calculated by subtracting nonspecific binding from total binding.

Miscellaneous methods. In order to observe the effect of PEM of monomeric IgA and secretory IgA levels in bile, sucrose density gradient centrifugation (20) was employed to separate these two forms of IgA. DNP-BGG was prepared by coupling 2,4-dinitrofluorobenzene and bovine $\gamma$-globulin(21). An immunoadsorbent, lightchain Sepharose 4B, was prepared by coupling rat light-chain with cyanogen bromide activated Sepharose 4B (Pharmacia) according to the method of Cuatrecasas(22). Rat light-chain was separated from heavy chain by gel filtration(23) following the reductive degradation(24) of rat IgG. Protein was determined by the method of Lowry et al.(25).

\section{RESULTS}

\section{Effect of protein-insufficient diets on the growth of rats}

The composition of diets is shown in Table 1. The feed consumption of rats fed $5 \%$ and $0.5 \%$ casein diet was less than that of control rats during the entire period (Table 2), indicating that the protein and energy intake were less in rats fed proteininsufficient diets than in control rats (Table 2). Tendencies to anorexia in rats were inversely related to casein levels in diets. Growth was severely retarded in rats fed $0.5 \%$ casein diet and moderately in rats fed 5\% casein diet (Fig. 1). In the last ten days of the experiment alopecia was observed in rats fed $0.5 \%$ casein diet.

Weight of the liver and the spleen were less in rats fed protein-insufficient diets, and atrophy of the thymus was a more drastic finding (Table 3). The thymus in rats

${ }^{2}$ Department of Nutrition, School of Health Sciences, Faculty of Medicine, University of Tokyo.

Vol. 29, No. 4, 1983 
Table 1. Composition of diets.

\begin{tabular}{|c|c|c|c|c|c|c|}
\hline & $\begin{array}{c}18 \% \\
(\mathrm{~g} / \mathrm{kg})\end{array}$ & $\begin{array}{l}\text { Casein } \\
(\mathrm{kcal} / \mathrm{kg})\end{array}$ & $\begin{array}{r}5 \% \\
(\mathrm{~g} / \mathrm{kg})\end{array}$ & $\begin{array}{l}\text { Casein } \\
(\mathrm{kcal} / \mathrm{kg})\end{array}$ & $\begin{array}{c}0.5 \% \\
(\mathrm{~g} / \mathrm{kg})\end{array}$ & $\begin{array}{l}\text { Casein } \\
(\mathrm{kcal} / \mathrm{kg})\end{array}$ \\
\hline Casein & 180 & 720 & 50 & 200 & 5 & 20 \\
\hline DL-Methionine & 1.8 & & 0.5 & & 0.05 & \\
\hline Cornstarch & 632 & 2,528 & 764 & 3,060 & 810 & 3,240 \\
\hline Salt mixture ${ }^{\mathrm{a}}$ & 50 & & 50 & & 50 & \\
\hline Cellulose & 25 & & 25 & & 25 & \\
\hline Vitamin mixture $^{\mathrm{b}}$ & 10 & & 10 & & 10 & \\
\hline Corn oil & 100 & 900 & 100 & 900 & 100 & 900 \\
\hline Total & & 4,148 & & 4,160 & & 4,160 \\
\hline
\end{tabular}

a Salt mixture (\%): $\mathrm{Ca}\left(\mathrm{H}_{2} \mathrm{PO}_{4}\right) \cdot 2 \mathrm{H}_{2} \mathrm{O}, 14.56 ; \mathrm{KH}_{2} \mathrm{PO}_{4}, 25.72 ; \mathrm{NaH}_{2} \mathrm{PO}_{4} \cdot \mathrm{H}_{2} \mathrm{O}, 9.35$; $\mathrm{NaCl}$, 4.46; calcium lactate, 35.09; ferric citrate, 3.18; $\mathrm{MgSO}_{4} \cdot 3 \mathrm{H}_{2} \mathrm{O}, 7.17 ; \mathrm{ZnCO}_{3}, 0.11$; $\mathrm{MnSO}_{4}, 0.03$; KI, 0.01. ${ }^{\mathrm{b}}$ Vitamin mixture (per $100 \mathrm{~g}$ ): vitamin A acetate, 5,000 IU; vitamin D, $10,000 \mathrm{IU}$; vitamin $\mathrm{B} 1,120 \mathrm{mg}$; vitamin $\mathrm{B} 2,400 \mathrm{mg}$; vitamin $\mathrm{B} 6,80 \mathrm{mg}$; vitamin B12, $0.05 \mathrm{mg}$; folic acid, $20 \mathrm{mg}$; calcium pantothenate, $10 \mathrm{mg}$; para-aminobenzoic acid, $500 \mathrm{mg}$; niacin, $600 \mathrm{mg}$; inositol, $600 \mathrm{mg}$; cholin chloride, $2,000 \mathrm{mg}$.

Table 2. Effect of casein levels on food, energy, and protein intake.

\begin{tabular}{|c|c|c|c|c|c|c|c|c|c|}
\hline \multirow{3}{*}{ Day } & \multicolumn{9}{|c|}{ Diets } \\
\hline & \multicolumn{3}{|c|}{$18 \%$ Casein } & \multicolumn{3}{|c|}{$5 \%$ Casein } & \multicolumn{3}{|c|}{$0.5 \%$ Casein } \\
\hline & $\begin{array}{l}\text { Food } \\
\text { intake }^{a}\end{array}$ & $\begin{array}{l}\text { Energy } \\
\text { intake }^{b}\end{array}$ & $\begin{array}{l}\text { Protein } \\
\text { intake }^{\mathfrak{c}}\end{array}$ & $\begin{array}{l}\text { Food } \\
\text { intake }\end{array}$ & $\begin{array}{c}\text { Energy } \\
\text { intake }\end{array}$ & $\begin{array}{c}\text { Protein } \\
\text { intake }\end{array}$ & $\begin{array}{l}\text { Food } \\
\text { intake }\end{array}$ & $\begin{array}{l}\text { Energy } \\
\text { intake }\end{array}$ & $\begin{array}{c}\text { Protein } \\
\text { intake }\end{array}$ \\
\hline $1-10$ & 13 & 54 & 2.3 & 8 & 33 & 0.4 & 7 & 29 & 0.04 \\
\hline $11-20$ & 13 & 54 & 2.3 & 8 & 33 & 0.4 & 5 & 21 & 0.03 \\
\hline $21-30$ & 12 & 50 & 2.2 & 8 & 33 & 0.4 & 4 & 17 & 0.02 \\
\hline $31-40$ & 10 & 41 & 1.8 & 9 & 37 & 0.5 & 4 & 17 & 0.02 \\
\hline Mean & 12 & 50 & 2.2 & 8 & 34 & 0.4 & 5 & 21 & 0.03 \\
\hline
\end{tabular}

${ }^{a}$ Food intake is expressed in $\mathrm{g} /$ day/rat. ${ }^{\mathrm{b}}$ Energy intake is calculated from food intake and energy content in diets and expressed in $\mathrm{kcal} / \mathrm{day} / \mathrm{rat} .{ }^{\circ}$ Protein intake is calculated from food intake and protein content in diets and expressed in $\mathrm{g} /$ day/rat.

fed $0.5 \%$ casein diet was represented grossly by only a few remaining strands of tissue. Thymus weight based on body weight of these rats was still significantly less than that of control rats.

Effects of protein-insufficient diets on immunoglobulin levels and DNP-lysine binding activities in serum

Serum albumin and total protein levels decreased in rats fed $5 \%$ or $0.5 \%$ casein 


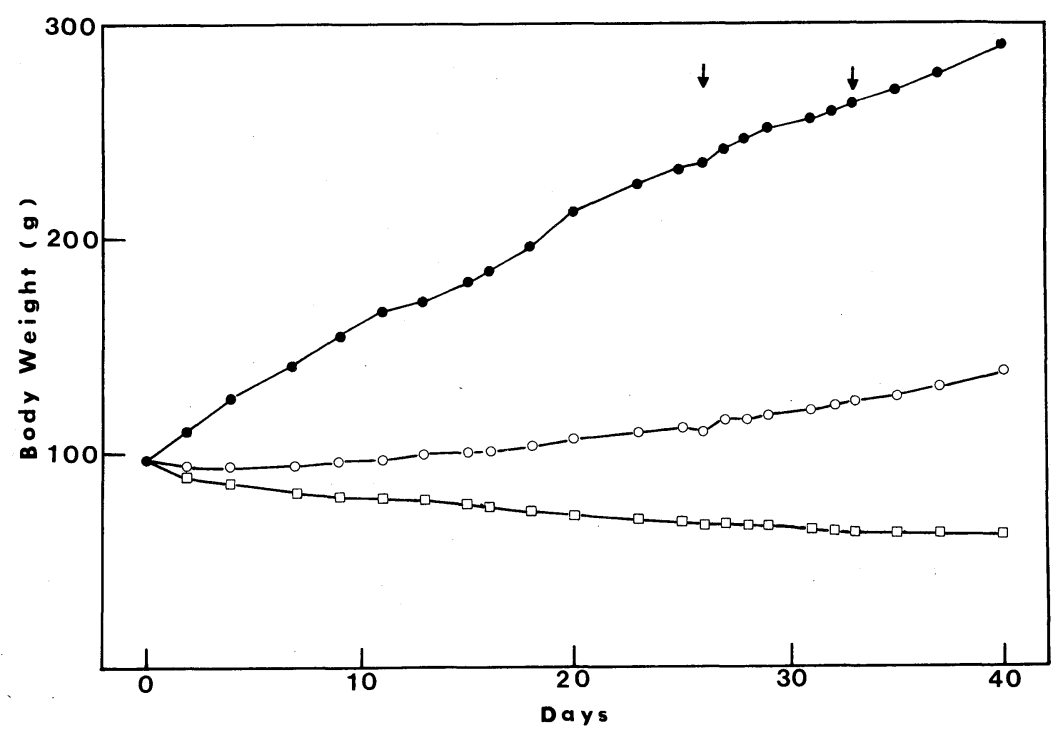

Fig. 1. Growth curves of rats fed $18 \%$ casein diet $(\bullet), 5 \%$ casein diet $(0)$, or $0.5 \%$ casein diet $(\square)$. Each point shows the mean body weight of six rats. Arrows show the injection of DNP-BGG.

Table 3. Effect of protein insufficient diets on organ weights.

\begin{tabular}{lccc}
\hline & \multicolumn{3}{c}{ Diets } \\
\cline { 2 - 4 } & $18 \%$ Casein & $5 \%$ Casein & $0.5 \%$ Casein \\
\hline Body weight (g) & $290 \pm 12^{* a * *}$ & $138 \pm 7^{\mathrm{b}}$ & $61 \pm 2^{\mathrm{c}}$ \\
& $9.8 \pm 1.0^{\mathrm{a}}$ & $4.6 \pm 0.6^{\mathrm{b}}$ & $2.3 \pm 0.2^{\mathrm{c}}$ \\
Liver (g) & $(3.6 \pm 0.3)^{* * *}$ & $(3.3 \pm 0.3)$ & $(3.7 \pm 0.2)$ \\
& $0.49 \pm 0.01^{\mathrm{a}}$ & $0.19 \pm 0.02^{\mathrm{b}}$ & $0.11 \pm 0.01^{\mathrm{c}}$ \\
Spleen (g) & $(0.17 \pm 0.01)$ & $(0.14 \pm 0.01)$ & $(0.17 \pm 0.02)$ \\
& $0.43 \pm 0.06^{\mathrm{a}}$ & $0.17 \pm 0.02^{\mathrm{b}}$ & $0.02 \pm 0.00^{\mathrm{c}}$ \\
Thymus (g) & $(0.14 \pm 0.02)^{\mathrm{a}}$ & $(0.12 \pm 0.02)^{\mathrm{a}}$ & $(0.04 \pm 0.01)^{\mathrm{b}}$ \\
\hline
\end{tabular}

${ }^{*}$ Mean \pm SE for six rats. ${ }^{* *}$ Means not followed by the same letter superscript are significantly different $(p<0.05) .{ }^{* * *}$ Values in parentheses are relative organ weights of $100 \mathrm{~g}$ body weight bases.

diet, and serum $\operatorname{IgG}$ and $\operatorname{IgA}$ levels were also low in these rats (Table 4). IgA levels were considerably lower than IgG levels in all groups, and no decrease in the ratio of IgA to IgG was observed in rats fed protein-insufficient diets.

Antibody responses to a T-cell dependent antigen, DNP-BGG, were evaluated Vol. 29, No. 4, 1983 
Table 4. Effect of protein insufficient diets on immunoglobulin levels and DNP-lys binding activities in serum.

\begin{tabular}{lccc}
\hline & \multicolumn{3}{c}{ Diets } \\
\cline { 2 - 4 } & $18 \%$ Casein & $5 \%$ Casein & $0.5 \%$ Casein \\
\hline Total protein $(\mathrm{mg} / \mathrm{ml})$ & $76.4 \pm 4.0^{* \mathrm{a} * *}$ & $66.4 \pm 2.9^{\mathrm{b}}$ & $50.6 \pm 2.0^{\mathrm{c}}$ \\
Albumin $(\mathrm{mg} / \mathrm{ml})$ & $38 \pm 2.0^{\mathrm{a}}$ & $29 \pm 2.0^{\mathrm{b}}$ & $21 \pm 1.0^{\mathrm{c}}$ \\
IgA $(\mu \mathrm{g} / \mathrm{ml})$ & $87 \pm 5.0^{\mathrm{a}}$ & $49 \pm 5.0^{\mathrm{b}}$ & $44 \pm 4.0^{\mathrm{b}}$ \\
IgG $(\mathrm{mg} / \mathrm{ml})$ & $3.9 \pm 0.5^{\mathrm{a}}$ & $2.6 \pm 0.2^{\mathrm{b}}$ & $2.2 \pm 0.3^{\mathrm{b}}$ \\
IgA/IgG & $0.023 \pm 0.02$ & $0.020 \pm 0.003$ & $0.021 \pm 0.002$ \\
Specifically bound & $44,326 \pm 8,793^{\mathrm{a}}$ & $28,400 \pm 1,981^{\mathrm{b}}$ & $482 \pm 116^{\mathrm{c}}$ \\
$\left.{ }^{3} \mathrm{H}\right]-\mathrm{DNP}-\mathrm{lys}(\mathrm{cpm} /$ precipitate) & & & \\
\hline
\end{tabular}

*All values are means for six rats \pm SE. ${ }^{* *}$ Means not followed by the same letter superscript are significantly different $(p<0.05)$.

Table 5. Effect of protein insufficient diets on immunoglobulin levels and DNP-lys binding activities in bile.

\begin{tabular}{lccc}
\hline & \multicolumn{3}{c}{ Diets } \\
\cline { 2 - 4 } & $18 \%$ Casein & $5 \%$ Casein & $0.5 \%$ Casein \\
\hline Total protein $(\mathrm{mg} / \mathrm{ml})$ & $4.06 \pm 0.28^{* \mathrm{a} * *}$ & $3.63 \pm 0.83^{\mathrm{a}}$ & $1.87 \pm 0.17^{\mathrm{b}}$ \\
Albumin (mg/ml) & $0.85 \pm 0.17^{\mathrm{a}}$ & $0.91 \pm 0.20^{\mathrm{a}}$ & $0.48 \pm 0.11^{\mathrm{b}}$ \\
IgA $(\mu \mathrm{g} / \mathrm{ml})$ & $243 \pm 21^{\mathrm{a}}$ & $180 \pm 20^{\mathrm{b}}$ & $102 \pm 16^{\mathrm{c}}$ \\
IgA/Total protein $(\%)$ & $5.9 \pm 0.6$ & $5.2 \pm 0.8$ & $5.7 \pm 1.2$ \\
IgA/Albumin $(\%)$ & $33 \pm 6$ & $25 \pm 5$ & $31 \pm 9$ \\
IgG $(\mu \mathrm{g} / \mathrm{ml})$ & $43 \pm 5^{\mathrm{a}}$ & $61 \pm 8^{\mathrm{a}}$ & $33 \pm 2^{\mathrm{b}}$ \\
IgG/Total protein $(\%)$ & $1.1 \pm 0.2^{\mathrm{a}}$ & $1.6 \pm 0.4^{\mathrm{ab}}$ & $1.9 \pm 0.4^{\mathrm{b}}$ \\
IgG/Albumin $(\%)$ & $6 \pm 2$ & $8 \pm 1$ & $10 \pm 2$ \\
IgA/IgG & $5.7 \pm 0.6^{\mathrm{a}}$ & $3.0 \pm 0.2^{\mathrm{b}}$ & $3.1 \pm 0.3^{\mathrm{b}}$ \\
Specifically bound & $3,418 \pm 917^{\mathrm{a}}$ & $2,438 \pm 563^{\mathrm{a}}$ & $318 \pm 105^{\mathrm{b}}$ \\
${ }^{3} \mathrm{H}$-DNP-lys (cpm/precipitate) & & & \\
\hline
\end{tabular}

*All values are means for six rats \pm SE. ${ }^{* *}$ Means not followed by the same superscript are significantly different $(p<0.05)$.

by specific binding activities to a hapten, DNP-lys. As shown in Table 4, DNP-lys binding activities in serum decreased in rats fed $5 \%$ or $0.5 \%$ casein diet. An extreme decrease in DNP-lys binding activities observed in rats fed $0.5 \%$ casein diet was 
apparently caused by severe thymic atrophy found in these rats.

\section{Effects of protein-insufficient diets on immunoglobulin levels and DNP-lysine binding} activities in bile

Decreases in biliary total protein and albumin levels were observed in rats fed $0.5 \%$ casein diet, whereas no significant decrease was observed in rats fed $5 \%$ casein diet (Table 5). IgA levels in bile were much higher than IgG levels in all groups. Biliary IgG levels decreased in rats fed $0.5 \%$ casein diet but not in rats fed $5 \%$ casein diet, while biliary $\operatorname{IgA}$ levels in rats fed protein-insufficient diets decreased relating to protein levels in the diets. The ratio of $\operatorname{IgA}$ to $\operatorname{IgG}$ also decreased in rats fed protein insufficient diets, and the decrease in the $\operatorname{IgA} / \operatorname{IgG}$ ratio was caused by particular effect of protein insufficient diets on biliary immunoglobulins, since no decrease in the $\operatorname{IgA} / \operatorname{IgG}$ ratio was shown in serum. DNP-lys binding activities in bile were extremely lower in rats fed $0.5 \%$ casein diet than control rats but not in rats fed $5 \%$ casein diet.

Since two forms of $\operatorname{IgA}$, monomeric $\operatorname{IgA}(7 \mathrm{~S})$ and $\operatorname{sIgA}(11 \mathrm{~S})$, may exist in bile, it was of interest to analyze which form of $\operatorname{IgA}$ was influenced by protein-insufficient

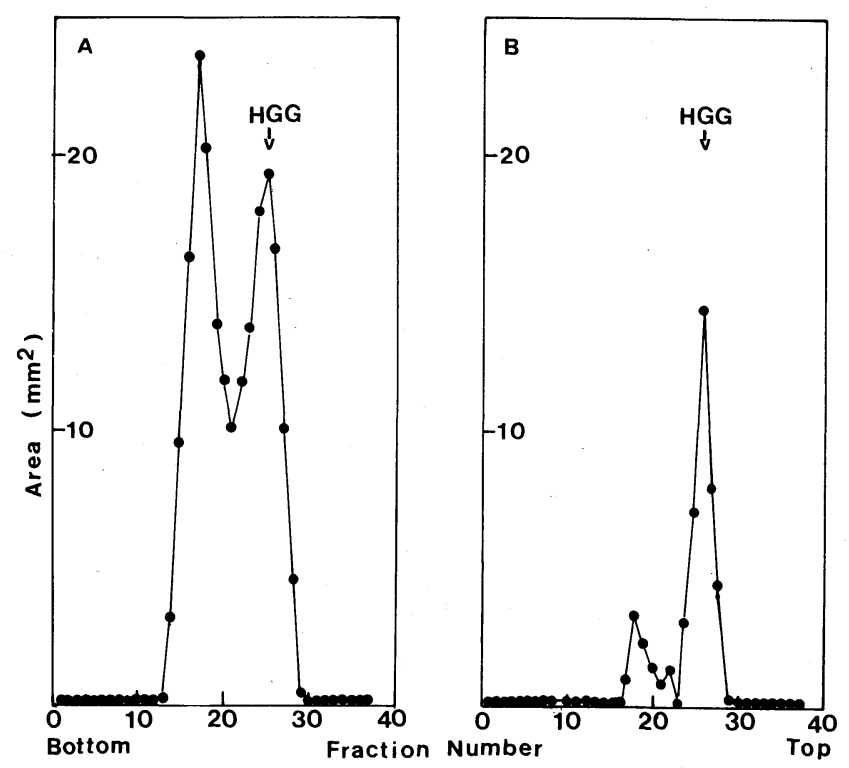

Fig. 2. Sedimentation patterns on sucrose gradient centrifugation of biliary IgA. $0.2 \mathrm{ml}$ of bile was applied on $5 \mathrm{ml}$ of continuous 5 to $20 \%$ (w/v) sucrose gradient in $2 \%$ $\mathrm{NaCl}, 10 \mathrm{~mm}$ Tris- $\mathrm{HCl}, \mathrm{pH} 8.0$. After centrifugation $216,000 \times g$ for $6 \mathrm{~h}$, the gradient was fractionated into $c a .40$ fractions of an equal volume. IgA was determined by radical immunodiffusion and the relative concentration of $\operatorname{IgA}$ (area of halo) $\left(\mathrm{mm}^{2}\right)$ was plotted. The sedimentation coefficient was estimated using human $\gamma$-globulin (7.0S) as a standard. Panels A and B show typical sedimentation patterns of IgA in bile obtained from rats fed $18 \%$ casein diet and $0.5 \%$ casein diet, respectively.

Vol. 29, No. 4, 1983 
diets. Figure 2 shows the representative sedimentation patterns on sucrose density gradient centrifugation of IgA in bile obtained from rats fed $18 \%$ and $0.5 \%$ casein diets, respectively. In rats fed $0.5 \%$ casein diet both 7S-IgA and $11 \mathrm{~S}-\mathrm{IgA}$ decreased, indicating a decrease in the total IgA level. It is also depicted that $11 \mathrm{~S}-\operatorname{IgA}$ decreased in these rats more remarkably than $7 \mathrm{~S}-\operatorname{IgA}$. This result shows that $\operatorname{sgA}$ is a more sensitive form of biliary $\operatorname{IgA}$.

\section{DISCUSSION}

The present study was undertaken to investigate the effect of PEM on biliary immunoglobulins in rats fed isocaloric diets containing $18 \%, 5 \%$, or $0.5 \%$ casein to produce an experimental model of PEM.

Growth was severely retarded in $0.5 \%$ casein diet-fed rats and moderately in $5 \%$ casein diet-fed rats. In these groups serum albumin and total protein levels decreased as predictable biochemical changes (26) associating with PEM. Although isocaloric diets were used in this experiment, the energy intake was low in rats fed protein-insufficient diets because of the decreased feed consumption. Consequently, the nutritional status of rats fed protein-insufficient diets was defined not as protein malnutrition but as protein-energy malnutrition. The decreased feed consumption in rats fed diets containing low levels of casein was reported by other investigators (27).

In the present study systemic immune functions in the protein-energy malnourished rats were shown to be depressed. Evidence was that serum IgG and IgA levels, and antibody responses to DNP-BGG decreased in these rats. The depressed systemic immune functions in the protein-energy malnourished rats are suggested to be caused by thymic atrophy. Thymus is known as an organ required for the maturation of T-lymphocytes (T-cells) (28). Since the production of IgA and IgG requires the interaction of B cells, namely precursor cells of antibody-producing cells, with matured T-cells (29), thymic atrophy will cause serum immunoglobulin levels to decrease. In addition, DNP-BGG is a T-cell dependent antigen which needs to be recognized by both T-cells and B-cells to express the antibody responses (30). Thus, the decreased DNP-lys binding activities in serum in the protein-energy malnourished rats may be caused by thymic atrophy. Cooper et al. show that the moderate deprivation in mice decreased the titer of serum antibody and the number of antibody-producing cells against sheep red blood cells (a T-cell dependent antigen), but did not change the antibody response to a $\mathrm{T}$-cell independent antigen, Brucella abortus(31). Considerable evidence has shown that protein-restricted diets reduced serum antibody responses to $\mathrm{T}$-cell dependent antigens (3).

In bile, IgA was shown to be a predominant immunoglobulin in good agreement with other investigators (11-14). In the present study biliary IgA levels were shown to decrease in both $5 \%$ and $0.5 \%$ casein diet groups relating to the protein levels in the diets. The ratio of $\operatorname{IgA}$ to $\operatorname{IgG}$ also decreased in rats fed proteininsufficient diets. Therefore, biliary IgA is a more sensitive responder to the PEM 
status than IgG. We have also shown in this study that sIgA decreased in severely malnourished rats more extremely than monomeric IgA. It is now recognized that biliary $\operatorname{sIgA}$ is derived from the serum pool of dimeric $\operatorname{IgA}$, and the secretion of sIgA via hepatic parenchymal cells into bile is dependent on combining dimeric IgA with SC which is synthesized in hepatic parenchymal cells $(13,18)$. Our data suggest that the secretion of IgA by hepatic parenchymal cells is depressed in protein-energy malnourished rats, in addition to that the production of IgA by plasma cells is depressed by thymic atrophy in these rats. Further studies are required to resolve the mechanism which depresses the IgA secretion in protein-energy malnourished rats, although the depressed synthesis of SC is predictable.

It is likely that biliary IgA has an important role in the local defense system of the intestinal tract. The decrease in biliary $\operatorname{IgA}$ antibodies will partly account for the increased susceptibility to intestinal infectious diseases associated with PEM.

\section{REFERENCES}

1) Scrimshaw, N. S., Taylor, C. E., and Gordon, J. E. (1968): Interactions of nutrition and infection, in WHO Monograph Series, No. 57, Chapter 4.

2) Chandra, R. K., and Newberne, P. M. (1977): Nutrition, Immunity and Infection, Plenum Press, New York.

3) Edelman, R. (1977): Cell-mediated immune response in protein-calorie malnutritionA review, in Malnutrition and the Immune Response, ed. by Suskind, R. M., Raven Press, New York, pp. 47-75.

4) Stiehm, E. R. (1980): Humoral immunity in malnutrition. Fed. Proc., 39, 3093-3097.

5) Beisel, W. R. (1980): Effects of infection on nutritional status and immunity. Fed. Proc., 39, 3105-3108.

6) Walker, W. A., and Isselbacher, K. J. (1977): Intestinal antibodies. New Engl. J. Med., 297, 767-773.

7) Tomasi, T. B., Jr., and Bienstock, J. (1968): Secretory immunoglobulins. $A d v$. Immunol., 9, 1-96.

8) Husband, A. J., and Watson, D. L. (1978): Immunity in the intestine. Veter. Bull., 48, 911-924.

9) Bienenstock, J., and Bufus, A. D. (1980): Review-Mucosal immunology. Immunology, 41, 249-270.

10) Koshland, M. E. (1975): Structure and function of the J chain. Adv. Immunol., 20, 41-69.

11) Lemaître-Coelho, I., Jackson, G. D. F., and Vaerman, J. P. (1977): Rat bile as a convenient source of secretory IgA and free secretory component. Eur. J. Immunol., 8, 588-590.

12) Lemaitre-Coelho, I., Jackson, G. D. F., and Vaerman, J. P. (1978): High levels of secretory $\operatorname{IgA}$ and free secretory component in the serum of rats with bile duct obstruction. J. Exp. Med., 147, 934-939.

13) Orlans, E., Peppard, J., Reynolds, J., and Hall, J. (1978): Rapid active transport of immunoglobulin A from blood to bile. J. Exp. Med., 147, 588-592.

14) Lemaitre-Coelho, I., Jackson, G. D. F., and Vaerman, J. P. (1978): Relevance of biliary IgA antibodies in rat intestinal immunity. Scand. J. Immunol., 8, 459-463. 
15) Lambert, R. (1965): Surgery of the bile and pancreatic ducts, in Surgery of the Digestive System in the Rat, Thomas, Springfield, Illinois, pp. 107-170.

16) Mancini, G., Carbonara, A. O., and Heremans, J. F. (1965): Immunochemical quantitation of antigens by single radial immunodiffusion. Immunochemistry, 2, 235254.

17) McGhee, J. R., Michalek, S. K., and Ghata, V. K. (1975): Rat immunoglobulins in serum and secretions. Purification of rat $\operatorname{IgM}, \operatorname{IgA}$, and $\operatorname{IgG}$, and their quantitation in serum, colostrum, milk, and saliva. Immunochemistry, 12, 817-823.

18) Fisher, M. M., Nagy, B., Bazin, H., and Underdown, B. J. (1979): Biliary transport of IgA: Role of secretory component. Proc. Natl. Acad. Sci. U.S.A., 76, 2008-2012.

19) Hanson, D. G., Vag, N. M., Maia, L. C. S., Hornbrook, M. M., Lynch, J. M., and Roy, C. A. (1977): Inhibition of specific immune responses by feeding protein antigens. Int. Arch. Allergy Appl. Immunol., 55, 526-532.

20) Martin, P. G., and Ames, B. N. (1961): A method for determining the sedimentation behavior of enzymes. J. Biol. Chem., 236, 1372-1379.

21) Dresser, D. W. (1978): in Handbook of Experimental Immunology, 3rd Ed., Vol. 2, Chapter 28, ed. by Weir, M. M., Blackwell Scientific Publications, Oxford.

22) Cuatrecasas, P., and Anfinsen, C. B. (1971): Affinity chromatography, in Methods in Enzymology, ed. by Colowick, S. P., and Kaplan, N. O., Academic Press, New York, p. 345 .

23) Fleishman, J. B., Pain, R. H., and Porter, R. R. (1962): Reduction of $\gamma$-globulins. Arch. Biochim. Biophys., 1, 174-180.

24) Gunewardena, P., and Cooke, K. B. (1966): 1,4-Dithiothreitol as a reagent for the reductive degradation of human $\gamma \mathrm{G}$ globulin. Biochem. J., 99, 8p.

25) Lowry, O. H., Rosebrough, N. J., Farr, A. L., and Randall, R. J. (1951): Protein measurement with the folin phenol reagent. J. Biol. Chem., 193, 265-275.

26) Suskind, R. M., Thanangkul, O., Damrongsak, D., Leitzmann, C., Suskind, L., and Olson, R. E. (1977): The malnourished child: clinical, biochemical, and hematological changes, in Malnutrition and the Immune Response, ed. by Suskind, R. M., Raven Press, New York, pp. 1-8.

27) Sakamoto, S., Kobayashi, S., Ishii, S., Suzuki, N., and Nishioka, K. (1978): Effect of malnutrition on complement level and tuberculin reactivity in the rats. Eiyo To Shokuryo (J. Jpn. Soc. Food Nutr.), 31, 49-58.

28) Incefy, G. S., L'Esperance, P., and Good, R. A. (1975): In vitro differentiation of human cells into $\mathrm{T}$ lymphocytes by thymic extracts using the rosette technique. Clin. Exp. Immunol., 19, 475-483.

29) Ebersole, J. L., Taubman, M. A., and Smith, D. J. (1979): Thymic control of secretory antibody responses in the rat. J. Immunol., 123, 19-24.

30) Katz, D. H., and Benacerraf, B. (1972): The regulatory influence of activated T cells on B cell responses to antigen. Adv. Immunol., 15, 2-94.

31) Cooper, W. C., Good, R. A., and Mariani, T. (1974): Effects of protein insufficiency on immune responsiveness. Am. J. Clin. Nutr., 27, 647-664. 